PHYSICS AND CHEMISTRY
OF SOLID STATE
v.21, No.2 (2020) pp. $227-231$

DOI: 10.15330/pess.21.2.227-231
Vasyl Stefanyk Precarpathian

National University

ФІЗИКА І ХІМІЯ ТВЕРДОГО ТІЛА

T. 21, № 2 (2020) C. 227-231

\author{
A.A. Druzhinin, I.P. Ostrovskii
}

\title{
Semiconductor Whiskers for Humidity Sensors
}

\author{
National university «Lvivska polytechnika»,Lviv, Ukraine, ihor.p.ostrovskyi@lpnu.ua
}

\begin{abstract}
In present paper p-type GaPAs whiskers doped with $\mathrm{Cu}$ were obtained by VLS method in close bromine system. The whiskers have various morphologies and geometries: imperfect needle-like crystals, ribbons, perfect needle-like crystals and thin plates. The whiskers of various morphologies serve as thermoresistores with TCR of about $1-2 \%$. The whisker I-U characteristics were investigated dependent on their geometry and external conditions (humidity). Voltage arising on the thermoresisor for two polarities of current passing through it was shown to be dependent on air humidity. Miniature semiconductor sensors of humidity based on GaPAs whiskers have been designed. Physical principles of operation, the perculiarities of design, and main performances of the microsensors were discussed. The whiskers of small diameter $(\mathrm{d}=50 \mu \mathrm{m})$ were shown to measure humidity in the range $\varphi=35 . . .97 \%$ with sensitivity to humidity $\gamma=\Delta \mathrm{U} / \mathrm{U} \varphi \approx 2.5 \cdot 10^{-3}$. The miniature dimensions of the whiskers provides very rapid response (of about a few sec) and small time of recovery (less than $30 \mathrm{sec}$ ).
\end{abstract}

Key words: whiskers, GaPAs, humidity, sensor.

Received 17 March 2020; Accepted 15 June 2020.

\section{Introduction}

Semiconductor whiskers have unique properties due to miniature dimensions leading to arising mesoscopic effects such as low temperature superconductivity [1], negative magnetoresistance [2], arising Berry phase [3] etc.. On the other side, they are prospective for design of microsensors of different physical values [4] including the sensors of humidity. The modern humidity sensors were elaborated using various materials, i.e. organic polymers [5] and ceramic materials [6]. In particular, efficient humidity sensors were prepared from microsized pyrolyzed bamboo [7]. The sensor has relatively high recovery time (less than $2 \mathrm{~min}$ ) and allows to measure humidity in wide range $20-96 \%$. The author [8] noted about a design of high sensitive humidity sensor based on $\mathrm{Ca}, \mathrm{Mg}, \mathrm{Fe}, \mathrm{Ti}$-oxide electro-ceramics with perovskite structures. The sensor shows a rapid response (14.5 s) and recovery (34.27 s), and very low hysteresis $(3.2 \%)$ in a $33-95 \%$ relative humidity range which are much lower values than those of existing conventional sensors. The main disadvantage of the sensor is relatively low sensitivity of the sensor in the range of humidity $30-70 \%$. The next elaborated sensor [9] is capacity sensor based on aluminum oxide. High sensitivity of the sensor is observed due to a numerous nanoporous in $\mathrm{Al}_{2} \mathrm{O}_{3}$ film. The improvement of the performances was obtained during heating the sensor. The heat of sensor leads to partial reduction of the sensor sensitivity, whereas a correction of nonlinearity and reduction of hysteresis occurs. The advantages of the above sensors are simplicity of preparation and design while the main shortcoming is comparatively high time of response.

Capasity sensors based on sensitive to humidity solid polymers and ceramics are used for measurement of humidity in the range $\varphi=20 \ldots 100 \%$. But such measurements are complicated due to the time relaxation of the $\Delta C=\mathrm{f}(\varphi)$ dependencies. The use of semiconductor microcrystals is more preferable for this purpose. In [10] thermoresistive sensors of humidity based on polysilicon using the standard CMOS fabrication is described. The sensor consists of $\mathrm{p}-\mathrm{n}$ junction and in the range of humidity $\varphi=40 \ldots 100 \%$ has very high sensitivity to humidity $\gamma=20 \mathrm{mV} / \% \mathrm{pH}$.

The present paper deals with the studies of characteristics of humidity microsensors based on GaPAs whiskers. The main principle of the sensor operation consists in use of overheated thermoresistors from GaPAs whiskers. Physical principles of operation, the 
perculiarities of design, and main performances of the above mentioned microsensors are discussed.

\section{Results and disscussion}

P-type GaPAs whiskers doped with $\mathrm{Cu}$ were obtained by VLS method in close bromine system [11]. $\mathrm{Au}$ contacts were made to the whiskers due to microprobe welding of $\mathrm{Au}$ microwire with diameter of about $10 \mu \mathrm{m}$. Than we study the humidity influence on performances of thermoresistors based on the whiskers. Humidity is shown to vary the conditions of heat exchange between the surroundings and the thermoresistor resulting in change of its resistance. ptype GaPAs whiskers doped with $\mathrm{Cu}$ having various morphologies and geometries are used as thermoresistors. The needle-like whiskers of various length $L=2 \ldots 7.5 \mathrm{~mm}$ and diameter $d=50 \ldots 200 \mu \mathrm{m}$ as well as ribbons with facet width $a=50 \ldots 200 \mu \mathrm{m}$ are under investigation. The crystal resistance at the room temperature was about $0.14 \ldots 7.5 \mathrm{M} \Omega$, the temperature coefficient of resistance $T C R=1 \ldots 2.2 \% / \mathrm{K}$. The main performances of the thermoresistors are presented in Table 1.

In the cases of imperfect needle-like crystals I-U characteristics of the thermoresistors were unlinear and the values of direct and reverse resistance could differ. Therefore, we measure voltages arising on the thermoresisor for two polarities of current passing through it (we use the regime of current stabilization in all the experiments). Difference of these voltages is shown to depend on the atmospheric humidity in the humidity range determined by the whisker morphology. The dependencies of voltage difference $\Delta U$ versus humidity $\varphi$ are presented in Fig. 1, Fig. 2, and Fig. 3 for thermoresistors TR-2, TR-3, and TR-4 with various morphology of GaPAs microcrystals (see Table 1), respectively. In these dependencies one may distinguish three typical regions of humidity:

- the first region, where voltage difference $\Delta U$ is almost independent on humidity $\varphi$ (see, for instance, Fig.1, where $\Delta U$ is constant in the range of humidity $\varphi=0 \ldots 80 \%)$;

- the second region, where considerable reduction of $\Delta U$ is found with increase of the humidity (see Fig. 1, where change of $\Delta U$ consists of about $4 \mathrm{~V}$ in the range of humidity $\varphi=90-93 \%$ );

- the third region, where $\Delta U$ is either independent on humidity ( $\varphi=97-100 \%$, see Fig. 2, and Fig. 3 for TR3 , and TR-4, respectively) or increases in $\sim 1 \mathrm{~V}$ with increase of humidity in the range $93-100 \%$ (TR-2, see Fig. 1).

Only the second region is useful for humidity measurement. Extent of the second region as well as value of $\Delta U$ change in the region are shown to depend essentially on the whiskers' morphology. If the whiskers' diameter decreases, the region is extended, while the

Table 1

Main performances of GaPAs thermoresistors (TR)

\begin{tabular}{|c|c|c|c|c|c|c|c|}
\hline Type of TR & $\begin{array}{c}R, \mathrm{M} \Omega, \\
300 \mathrm{~K}\end{array}$ & $\begin{array}{c}\rho, \Omega \cdot \mathrm{cm}, \\
300 \mathrm{~K}\end{array}$ & $T C R, \% / K$ & $L, \mu \mathrm{m}$ & $a, \mu \mathrm{m}$ & $S_{d}, \mu \mathrm{m}^{2}$ & $\begin{array}{c}\text { Whisker } \\
\text { morphology }\end{array}$ \\
\hline TR-1 & 0.145 & 15.7 & 2.19 & 4000 & 100 & 4330 & $\begin{array}{c}\text { Imperfect } \\
\text { needle-like } \\
\text { crystals }\end{array}$ \\
\hline TR-2 & 0.78 & 180 & 2.78 & 7500 & 200 & 17320 & $\begin{array}{c}\text { Needle-like } \\
\text { crystals }\end{array}$ \\
\hline TR-3 & 7.5 & 692 & 1.13 & 6500 & $\begin{array}{c}200 \\
30\end{array}$ & 6000 & $\begin{array}{c}\text { Ribbon } \\
\text { TR-4 }\end{array}$ \\
\hline TR-5 & 1.5 & 16.9 & 1.23 & 5000 & 62.5 & 1691.4 & $\begin{array}{c}\text { Perfect needle- } \\
\text { like crystals }\end{array}$ \\
\hline
\end{tabular}
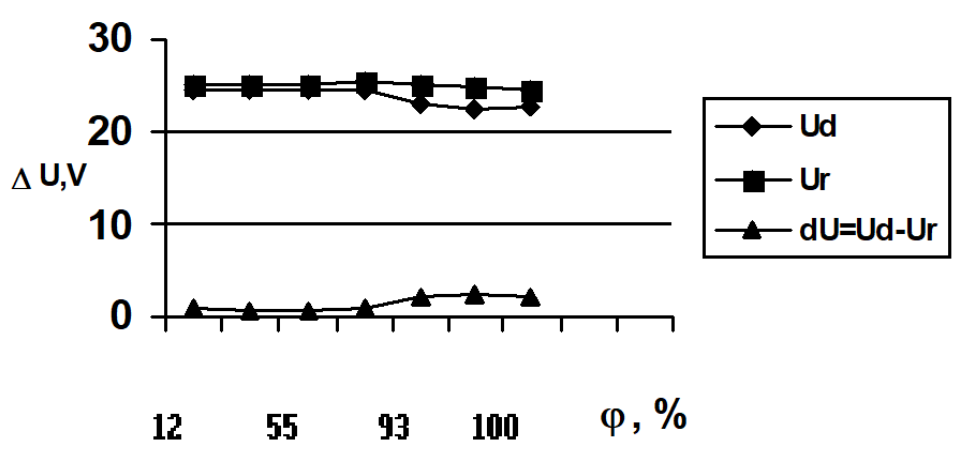

Fig. 1. Voltage difference $\Delta U$ between direct and reverse voltages of thermoresistor TR-2 versus humidity $\varphi$ dependency at different values of current $I$ through the thermoresistor 


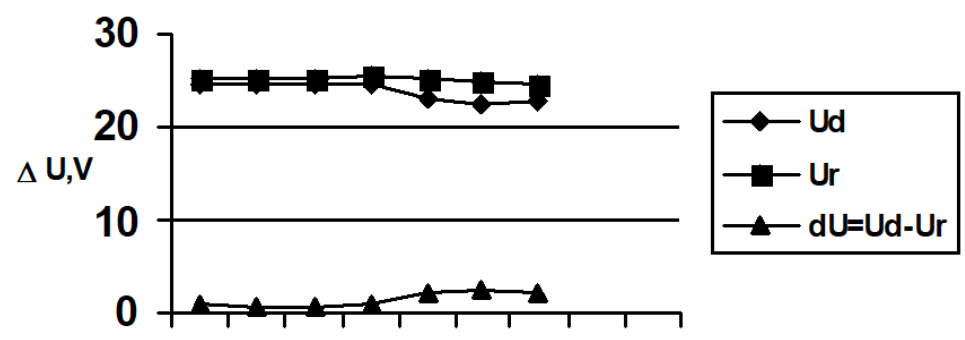

$\begin{array}{lllll}12 & 55 & 93 & 100 & \varphi, \%\end{array}$

Fig. 2. Voltage difference $\mathrm{d} U$, direct (Ud) and reverse (Ur) voltages of thermoresistor TR-3 versus humidity $\varphi$ dependency.

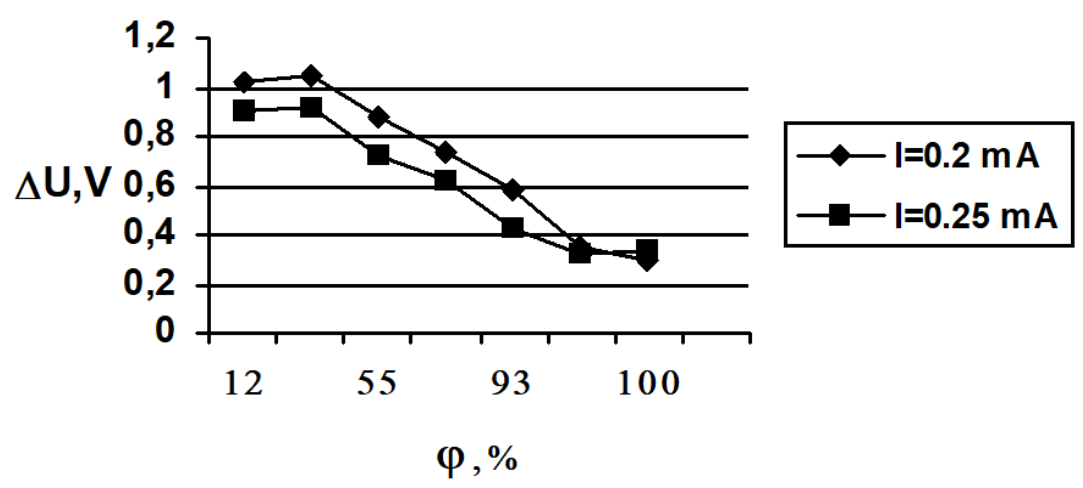

Fig. 3. Voltage difference $\Delta U$ between direct and reverse voltages $U$ of thermoresistor TR-3 versus humidity $\varphi$ dependency.

value of $\Delta U$ change reduces. The direct voltage $U$ reduces from its maximum to minimum value in about $2 \mathrm{~V}$ in the range of humidity $70 \ldots 97 \%$ for TR-3 $(a=200,30 \mu \mathrm{m})$ (see Fig. 2), whereas the $\Delta U$ value changes in about $1 \mathrm{~V}$ (at $\mathrm{I}=0.2 \mathrm{~mA}$ ) in the range of humidity $33 \ldots 97 \%$ for TR-4 $(d=50 \mu \mathrm{m})$ (see Fig. 3 ).

To explain the dependencies of the thermoresistor voltage on humidity two effects should be taken into account: 1) heat transfer from the thermoresistor to the environment and 2) change which occurs in the electrical contacts owing to humidity influence. The former corresponds to arising of the first region of humidity, while the latter is responsible for observing of the second region of humidity. Transition between these regions occurs at a certain critical humidity $\varphi_{\mathrm{cr}}$.

To estimate the heat transfer to the environment we calculated some thermal parameters of the thermoresistors. Among them there are the coefficient of heat transfer $\alpha$, the temperature of overheating $T_{h}$ (it is a temperature of thermoresistor heated by the electrical current), the coefficient of heat dissipation $H$, and dissipated power $P$. The parameters at selective values of humidity are presented in Table 2 . As shown in Table 2, $\alpha$ as well as $T_{h}$ values depend strongly on the whisker morphology. In general $\alpha$ is determined by the heat transfer from volume $V$ of a crystal through its surface $S$ in the environment, i.e., by a ratio of $S / V$. Below we present (Table 3 ) the average values of $\alpha$ and the ratio
$S / V$ for the thermoresistors. A good agreement between these parameters is observed. If the ratio $S / V$ increases, $\alpha$ value also increases, while temperature of overheating $T_{h}$ decreases (see Table 3).

The influence of humidity can be explained by the following consideration. The heat conduction of water vapour is in order of magnitude higher than that of an air. Therefore, the heat transfer increases at rise of humidity leading to the reduction of the temperature $T_{h}\left(\right.$ see $T_{h 1}$ and $\mathrm{T}_{\mathrm{h} 2}$ in Table 2) of the thermoresistor and, as a result, to the increase of its resistance (voltage). That is why we observe a weak increase of voltage at humidity rise in the first region of humidity (see, for instance, the dependency $U=\mathrm{f}(\varphi)$ for TR-3, Fig. 2). A change of the thermoresistor resistance (voltage) with temperature decrease should be larger at lower temperature of thermoresistor due to exponential dependency $R(T)$ for GaPAs $\langle\mathrm{Cu}>$ whisker. This explains larger changes of $\Delta U$ in the dependency $\Delta \mathrm{U}=\mathrm{f}(\varphi)$ for TR-4 (see Fig. 3) than those of TR-3 (see Fig. 2) in the range of humidity less than $\varphi_{\mathrm{cr}}$.

Whence the humidity values are over $\varphi_{\mathrm{cr}}$ a content of water in vapour becomes enough to change the parameters of the whisker contacts. This assumption is confirmed by a correlation found between the value of $\Delta U$ change in the second region of humidity and area of the whisker cross section $S_{d}$ (see Table 3). The higher $S_{d}$, the larger $\Delta U$ is. Humidity likely leads to the increase of 
Table 2

The main thermal parameters of thermoresistors

\begin{tabular}{|c|c|c|c|c|c|c|c|c|c|c|c|c|c|}
\hline \multirow[t]{2}{*}{$\begin{array}{l}\text { Type } \\
\text { of TR }\end{array}$} & \multirow{2}{*}{$\begin{array}{c}\text { Humidity, } \\
\% \\
\text { Current, } \\
\text { mA }\end{array}$} & \multicolumn{3}{|c|}{$\begin{array}{c}\text { Temperature of } \\
\text { overheating, } \\
\text { K }\end{array}$} & \multicolumn{3}{|c|}{$\begin{array}{l}\text { Coefficient of heat } \\
\text { transfer, } \mathrm{W} / \mathrm{m}^{2} \cdot \mathrm{K}\end{array}$} & \multicolumn{3}{|c|}{$\begin{array}{l}\text { Coefficient of } \\
\text { dissipation, } \\
\mathrm{mW} / \mathrm{K}\end{array}$} & \multicolumn{3}{|c|}{$\begin{array}{l}\text { Dissipated power, } \\
\mathrm{mW}\end{array}$} \\
\hline & & $T_{h_{1}}$ & $T_{h_{2}}$ & $T_{h_{3}}$ & $\alpha_{1}$ & $\alpha_{2}$ & $\alpha_{3}$ & $H_{1}$ & $H_{2}$ & $H_{3}$ & $P_{1}$ & $P_{2}$ & $P_{3}$ \\
\hline \multirow[b]{3}{*}{$T R-2$} & $\varphi, \%$ & 12 & -- & 93 & 12 & -- & 93 & 12 & -- & 93 & 12 & -- & 93 \\
\hline & 1.0 & 476 & -- & 482 & 28.2 & -- & 25.6 & 0.13 & -- & 0.12 & 23.2 & -- & 21.8 \\
\hline & $\varphi, \%$ & 12 & 75 & 99 & 12 & 75 & 99 & 12 & 75 & 99 & 12 & 75 & 99 \\
\hline \multirow[t]{2}{*}{$T P-3$} & 1.0 & 400 & 392 & 403 & 88 & 95.6 & 79.2 & 0.23 & 0.25 & 0.21 & 24.5 & 24.6 & 22.7 \\
\hline & $\varphi, \%$ & 12 & 33 & -- & 12 & 33 & -- & 12 & 33 & -- & 12 & 33 & -- \\
\hline \multirow[b]{2}{*}{$T P-4$} & 0.20 & 362 & 363 & -- & 123 & 121.8 & -- & 0.12 & 0.11 & -- & 8.0 & 7.99 & -- \\
\hline & 0.25 & 377 & 363 & -- & 145.8 & 177.8 & -- & 0.14 & 0.17 & -- & 11.5 & 11.7 & -- \\
\hline
\end{tabular}

capacity $C$ of the whisker contact due to rise of $\varepsilon$ in $C=\varepsilon \varepsilon_{0} S_{\mathrm{d}} / d$, with $\varepsilon_{o}$ as the dielectric constant, $d$ as the whisker diameter. Then the contact resistance as well as voltage on the thermoresistor should reduce at humidity rise as it is observed, e.g., in Fig. 3. At higher temperature of the thermoresistor the critical concentration $\varphi_{c r}$ shifts in the region of larger values of humidity (see Table 3 ). We observe a linear dependency of temperature of overheating $T_{h}$ on critical value of humidity $\varphi_{c r}$ (see Table 3 ). By extrapolation of linear dependency $\varphi_{c \mathrm{r}}=\mathrm{f}\left(T_{h}\right)$ to $\varphi=100 \%$ we determined the temperature $T_{h} \approx 510 \mathrm{~K}$ of thermoresistor for which the second region of humidity should not be observed due to the strong water evaporation. The extrapolation of $\varphi_{c r}=\mathrm{f}\left(T_{h}\right)$ dependency to $\varphi=0$ gives us a value $T_{h}$ close to the room temperature, i.e., the thermoresistor is not overheated and the first region of humidity vanishes. The thermoresistor with such characteristics (operating in the wide range of humidity $\varphi=0 \ldots 100 \%$ ) can be fabricated of the whisker of small diameter $(d=20-30 \mu \mathrm{m})$.

\section{Table 3}

Performances of GaPAs thermoresistors

\begin{tabular}{|c|c|c|c|}
\hline Parameters & TR-2 & TR-3 & TR-4 \\
\hline$a, \mu \mathrm{m}$ & 200 & 200,30 & 62.5 \\
\hline$S / V$ & 0.02 & 0.05 & 0.08 \\
\hline$\alpha, \mathrm{W} / \mathrm{m}^{2} \mathrm{~K}$ & 28 & 85 & 120 \\
\hline$T_{h}, \mathrm{~K}$ & 478 & 396 & 370 \\
\hline$\varphi_{c r}, \%$ & 90 & 70 & 33 \\
\hline$S_{d}, \mu \mathrm{m}^{2}$ & 17000 & 6000 & 1700 \\
\hline$\Delta U, \mathrm{~V}$ & 4 & 2 & 1 \\
\hline
\end{tabular}

As a result of the above consideration we make the following conclusions. The thermoresistors with GaPAs whiskers are sensitive to humidity. The complex dependency of the thermoresistor voltage on humidity $\Delta U=\mathrm{f}(\varphi)$ is observed. It contains few typical regions of humidity. Calculation of thermal parameters of the thermoresistor allows to explain a character of the $\Delta U=$ $\mathrm{f}(\varphi)$ dependency:

a) behaviour of the thermoresistor voltage in the first region of humidity in the dependency $\Delta U=\mathrm{f}(\varphi)$ is caused by the heat transfer in the surroundings;

b) an appearance of the second region of humidity on the dependency $\Delta U=\mathrm{f}(\varphi)$ is correspondent to decrease of the contact resistance due to humidity influence.

Extent of the regions of humidity is shown to depend strongly on the whisker morphology, determining the whiskers' application. The thermoresistor with GaPAs whisker of large diameter $(d=200 \mu \mathrm{m})$ can be used for automatic control of humidity at $\varphi=90 \ldots 100 \%$. Sensors based on perfect ribbons and needle-like crystals with small diameter $(d=50 \mu \mathrm{m})$ allows to measure humidity in the range $\varphi=60 \ldots 100 \%$ and $\varphi=35 \ldots 97 \%$ respectively. Sensitivity to humidity $\gamma=\Delta \mathrm{U} / \mathrm{U} \varphi \approx$ $2.5 \cdot 10^{-3}$. Use of thin whiskers with diameter $d<30 \mu \mathrm{m}$ gives an opportunity to extend the range of measured humidity.

\section{Conclusions}

P-type GaPAs whiskers were grown in closed bromine system. VLS method of growth provides various morphologies of the whiskers: imperfect needle-like crystals, ribbons, perfect needle-like crystals and thin plates. The whiskers have the dimensions of about $50-200 \mu \mathrm{m}$. I-U characteristics of the whiskers were obtained using the regime of current stabilization in all the experiments. The values of direct and reverse voltage at I-U characteristics was shown to differ dependently on the humidity of air. Difference of these voltages is shown to depend on the atmospheric humidity in the humidity range determined by the whisker morphology. The main physical reason of the effect is a change of the capacity of the whisker contacts on the whiskers ends due to a difference of condensed water in humidity air.

Semiconductor whiskers were shown to be successfully applied as sensors of humidity. Different effects of humidity influence on the whisker parameters were found. In particular, thermoresitors from GaPAs whiskers are sensitive to humidity in the range of humidity depending on the whisker morphology. The whiskers of small diameter $(\mathrm{d}=50 \mu \mathrm{m})$ were shown to measure humidity in the range $\varphi=35 . . .97 \%$ with sensitivity to humidity $\gamma=\Delta \mathrm{U} / \mathrm{U} \varphi \approx 2.5 \cdot 10^{-3}$. The miniature dimensions of the whiskers provides very rapid response (of about a few sec) and small time of recovery (less than $30 \mathrm{sec}$ ). 
Druzhinin A.O. - Dr. Sci., technical science, Professor, Department of semiconductor electronics;
Ostrovskii I.P. - Dr. Sci., technical science, Professor, Department of semiconductor electronics.

[1] A. Bezryadin, Journal of Physics: Condensed Matter. 20(4), 043202 (2008) (doi: 10.1088/09538984/20/04/043202).

[2] A. Druzhinin, I. Ostrovskii, Y. Khoverko, N. Liakh-Kaguy, Low Temperature Physics 45(5), 513 (2019) (doi:10.1063/1.5097360).

[3] A. Druzhinin, I. Ostrovskii, Y. Khoverko, N. Liakh-Kaguy, Journal of Low Temperature Physics 196(3-4), 375 (2019) (doi:10.1007/s10909-019-02189-4).

[4] F. Patolsky, G. Zheng,, Ch.Lieber, Nanomedicine 1(1), 51 (2013) (doi.org/10.2217/17435889.1.1.51).

[5] M.V. Kulkarni, A.K. Viswanath, P. Khanna, Sens. Actuators B Chem. 115, 140 (2006) (doi:10.1016/j.snb.2005.08.031).

[6] J. Shah, R. Kotnala, B.Singh, H. Kishan, Sens. Actuators B Chem, 128, 306 (2007) (doi:10.1016/j.snb.2007.06.021).

[7] A.S. Afify, S. Ahmad, R.A. Khushnood, P. Jagdale, J.M. Tulliani, Sensors and Actuators B: Chemical 239, 1251 (2017) (doi:10.1016/j.snb.2016.09.130).

[8] A. Tripathy, S. Pramanik, A. Manna, S. Bhuyan, N.F.A. Shah, Z. Radzi, and N.A. Osman, Sensors 16, 1135 (2016) (doi:10.3390/s16071135).

[9] Y. Kim, B. Jung, H. Lee, H. Kim, K. Lee, H. Park, Sensors and Actuators B: Chemical 141(2), 441 (2009) (doi:10.1016/j.snb.2009.07.007).

[10] B. Okcan and T. Akin, 17th IEEE International Conference on Micro Electro Mechanical Systems (Maastricht, Netherlands, 2004), p. 552.

[11] A.A. Druzhinin, I.P. Ostrovskii, Physica status solidi (c) 1(2), 333 (2004) (doi:10.1002/pssc.200303948).

\title{
А.О. Дружинін, І.П. Островський
}

\section{Напівпровідникові ниткоподібні кристали для сенсорів вологості}

\author{
Національний університет «Львівська політехніка», Львів, Украӥна, ihor.p.ostrovskyi@lpпи.иа
}

У статті розглядаються характеристики ниткоподібних кристалів GaPAs p-типу провідності, легованих $\mathrm{Cu}$, які були отримані за механізмом пара-рідина-кристал у закритій бромідній системі. Отримані кристали різної морфології та геометрії: недосконалі голкоподібні кристали, стрічки, ідеальні голкоподібні кристали та тонкі пластинки. Ниткоподібні кристали різної морфології використовувалися як терморезистори 3 ТКО близько $1-2 \%$. Досліджувалися вольт-амперні характеристики кристалів залежно від їх геометрії та зовнішніх умов (нормальні умови, зміна вологості). Показано, що напруга, яка виникає на терморезисторі для двох полярностей струму, що проходить через нього, залежить від вологості повітря. Розроблені мініатюрні напівпровідникові датчики вологості на основі ниткоподібних кристалів GaPAs. Обговорюються фізичні принципи роботи, особливості конструкції та основні характеристики мікросенсорів. Ниткоподібні кристали невеликого діаметру $(\mathrm{d}=50$ мкм) придатні для вимірювання вологості в межах $\varphi=35 \ldots 97 \%$ при чутливості до вологості $\gamma=\Delta \mathrm{U} / \mathrm{U} \varphi \approx 2,5 \cdot 10^{-3}$. Мініатюрні розміри ниткоподібних кристалів забезпечують дуже швидку реакцію (декілька секунд) $\mathrm{i}$ невеликий час відновлення (менше 30 сек)

Ключові слова: ниткоподібні кристали, GaPAs, вологість, сенсори. 